\title{
New Product Introduction Prize (NPIP) and the Market Value of the Firm: An Empirical Investigation into the Computer, Electronic and Communication Industry (CECI)
}

\author{
Isaac Quaye \\ School of Management and Economics, \\ University of Electronic Science and Technology of China (UESTC), \\ Chengdu, China \\ Yinping Mu \\ School of Management and Economics, \\ University of Electronic Science and Technology of China (UESTC), \\ Chengdu, China \\ Braimah Abudu \\ School of Management and Economics, \\ University of Electronic Science and Technology of China (UESTC), \\ Chengdu, China \\ Alfred Sarbah \\ Institute of Distance Learning and Continuing Education, \\ Kumasi Technical University, \\ Kumasi-Ghana
}

\begin{abstract}
This research studies the effect of new product introduction prize (NPIP) announcements on firm value, applying event study methodology to 509 NPIP announcements between the period of 2001-2015. Specifically, the study focuses on NPIP announcements made in the computer, electronic and communication industry (CECI). It analyzes the short-term effect of market value caused by NPIP announcements within two-day event window (Days -1 and 0 ) by using market model. We established that NPIP announcements are perceived by investors as positive news, resulting in significant positive cumulative abnormal returns (CARs). Having controlled for firm-specific effects, (reputation and R\&D intensity), we observed that stock market responds more positively to NPIPs attained by small-sized firms than large-sized firms. In addition, stock market reaction to firms that won NPIP from third-party prize schemes is more positive than winning from prize schemes within the firms' supply chain. Due to the indispensable financial rewards accumulated by firms winning NPIPs, the conclusions of this research are very valuable to managers in the allocation of more resources towards augmenting their firms' new product development capabilities.
\end{abstract}

Keywords: Stock Market Reaction, Event Study, Abnormal Returns, Market Performance, NPIP

JEL Classification: G10, G11, G14

\section{INTRODUCTION}

Industry awards can be a valuable addition to your marketing arsenal. The free publicity an award-winning business receives can result in more business and new connections, helping to validate what your company does and increasing your visibility in the marketplace [1]. 
This quotation reflects the inevitable extrinsic and intrinsic benefits that accrue to firms winning prizes or awards. As such it is imperative for firms to set and strive to achieve objectives of introducing new and innovative goods and services which have the tendency of winning prizes or awards. The launch of new products signifies the firm's technical development capabilities which are regarded as knowledge and skills converted into profitable products. The presence of a new product can be seen as a means of learning which assumes a cumulative process for knowledge endowment; therefore, an array of new products introduced on display may be a manifestation of a higher inventory of knowledge [2]-[5]. According to [6], competitive advantage and differentiation are some of the advantages created by new product introductions (NPIs) and consequently can have a favorable effect on the announcing firm's stock price. The benefits of NPIs by firms are further highlighted by [7]. The authors enumerated four importance of NPIs as follows:

i. firm growth and higher sales are achieved through introducing new products which incorporated advanced capabilities and features.

ii. through introducing new products, firms can target segments that yield high margins in order to boost their profitability levels.

iii. the churning out of new products can enable firms to cut costs by focusing on their existing consumers with their new products rather than incurring additional costs to finding new customers for their new and older products.

iv. the firm's new product development competences may be transformed and allow the firm to reap profit for a long period of time.

Firms must be better at developing new products in an increasingly competitive global economy. As such it is critical for firms to develop and implement effective strategies in their new product development processes in order to maintain their competitiveness in the market. However, a winning strategy that has emerged and proven to ensure high level of competitiveness recently is the time-based competition strategy [8]. According to [9], the fundamental idea of time-based competition is about reducing the time allotted to every stage of general cycle including planning, designing, creation of product, introduction of innovation, supply, marketing and distribution with each stage revolving consumer needs and expectations. Therefore, time-based competition emphasizes that those who want to sustain competitive advantage and higher market share must consider the speed at which they introduce new products as the catalyst for achieving such objectives [10]. [11] support this assertion and posit that speed has become, if not the critical competency, a critical competency for companies large and small, domestic and foreign. Furthermore, [12] report that the greater the chance for a firm to overrun its competitors is dependent on the faster rate it launches new product into the market.

Time-based competition strategy has largely been adopted and implemented in fast-cycle industries where the life cycles of products relatively short period of time which is usually two years or less [13]. Amongst such industries which has experienced rapid technological and proliferation of NPIs is the CECI. The basic features of this industry, according to [7], are regular NPIs, relaxed entry and exit for firms as well as the inability for a firm maintain competitive advantage for longer period of time. The short product life cycles amongst firms in the CECI is evidenced in Figure 1 which depicts the life cycle of all Apple's iPhone models. 


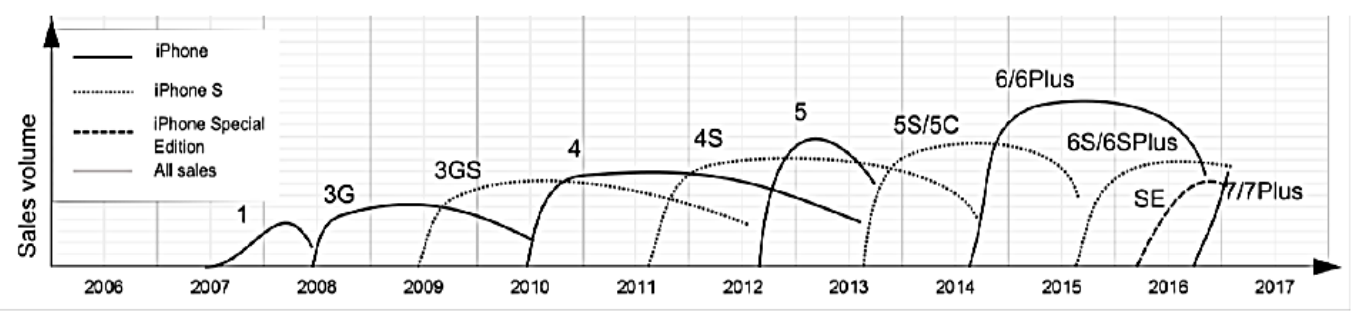

Figure 1: Life cycle of all iPhone models Source: [13]

Comparatively, the CECI has been growing and developing relatively faster pace than the other industries in the last 30 years [14]. This means that their NPI rate is higher than other industries. That notwithstanding, scanty studies exist on the impact of NPIs on the value of firms in CECI. Most studies undertaken on the effect of NPIs on shareholders wealth are not industry-specific [15]-[20]. [7], [21] are some of the scanty solid researches conducted on how NPIs impact firms' performances in CECI. Consequently, this research contributes significantly to the exiguous literature with regard to new product announcements and their effects on firm value in the CECI. Apart from the aforementioned copious benefits of NPI, successful new products have the tendency to be awarded a NPIP by some prize-giving institutions. Many NPIP schemes enumerate some benefits which accrue to firms winning prizes. For instance, a firm which wins an HME Business 2018 New Product Award will receive great publicity including [22]:

- recognition and award at Medtrade Fall 2018

- use of HME Business 2018 New Product Award logo for one year on all ads, social media, and marketing materials

- recognition in HME Business marketing and promotions

- editorial coverage, both online and in print, and special advertising rates in the December 2018 issue of HME Business magazine

From the perspective of managers and decision-makers, being awarded NPIP is a means of reaffirming before shareholders that suitable decisions were taken in the context of agency conflicts avoidance [23]. In terms of the firm's viewpoint, it is an avenue to portray differentiation to the marketplace [24]. Furthermore, winning NPIP will deepen the loyalty of existing customer and attract new ones to patronage the product of the prize-winning firm. Winning such a prize is a means of communicating to existing and potential customers about the effectiveness of management decisions in producing quality goods and services to meet the ever-changing customer needs. A crucial aim of the prize-giving institutions is to acknowledge firms that have launched outstanding products within the year under consideration. Prizewinning firms are chosen after conducting an independent assessment and evaluation of the firms' products by the use of pre-defined criteria such as external interactions, functionality, user interactions, architecture and cost [25]. There exists plethora of NPIP schemes such as "Stevie" Award for Best New Product, FOSE Best New Technology Award, Computing Awards for Excellence, Most Innovative New Product (MIP) Awards, European Electronics Industry Awards, CompTIA Best New Product Award, and many more. Table 1 presents description some of the prize-giving institutions whose winners were included in the sample used for this study. 
Table 1. Some of the prize-giving institutions whose winners are included in the sample

\begin{tabular}{l}
\hline Prize-Giving \\
Institutions \\
\hline Outstanding \\
Corporate Innovator \\
(OCI) Award \\
Most Innovative New \\
Product (MIP) \\
Awards \\
CompTIA "Best New \\
Product" Award
\end{tabular}

XCellence XChange

Awards

Stevie Award for

Best New Product

FOSE Best New

Technology Award

National Marine

Electronics

Association (NMEA)

Technology Award

Best of Show Award

SuperQuest Awards

Product Innovation Award

SIIA Annual Codie Awards

National Society of

Professional

Engineers (NSPE)

New product Awards

Networking Industry

Awards

Frost \& Sullivan

Market Engineering

Award

COMNET New

Product

Achievement Awards

European

Electronics Industry

Awards
The OCI Award is presented to showcase those organizations who are the most successful in developing new products and have an enterprise-wide commitment to innovation.

The MIP Awards is where CONNECT continues its annual tradition in honoring San Diego's celebrities of innovation along with groundbreaking new products launched within the last year.

CompTIA "Best New Product" award recognizes conference attendees' choice for achievement and innovation in network and security management solutions. CompTIA has a long tradition of honoring the best IT solutions. The awards are a mark of distinction and achievement in an extremely marketplace.

The XCellence XChange awards are presented to top software, hardware products and strategies in the Best New Software category.

Stevie Award for Best New Product includes all product management, product development, product engineering, manufacturing, etc. New Products and services released in USA since January 1 of every year are eligible to be nominated.

The FOSE Best New Technology is the most prestigious honor presented to products designed to meet the need of government IT professionals which are recognized by the judges as the best new storage products of the year.

The annual NMEA Technology Award is awarded to new products based on innovation, benefit to boaters, practicality and value.

The Best of Show Awards Program recognizes the most innovative personal technology and corporate IT products, solutions and programs at the event. To qualify, firms had to be announcing a new business IT product/solution or demonstrating it for the first time at the event.

SuperQuest Awards honors the best-built networks and most promising new technologies among SUPERCOMM exhibitors and their customers worldwide. The recipient of Product Innovation Award is determined through an extensive study of product developments, new product launches, and research and development spending within the industry and is awarded for a high degree of innovation and customer satisfaction.

The annual Codie awards showcases the software and information industry's finest products and services and remains the standard bearer for celebrating outstanding achievement and vision in the industry.

The purpose of NSPE New Product Award program is to recognize the full spectrum of benefits that come from the research and engineering of new products.

The Networking Industry Awards' independent panel of judges, who were looking for the most innovative products of the year, evaluate entrants based on the following criteria: functionality, features, innovation, performance, configuration, resilience, ease-of-use, price, fitness for purpose and market position.

The Frost \& Sullivan Market Engineering Award for Product Innovation is awarded each year to a company demonstrating excellence in new products and technologies within their industry.

Entries are evaluated on the basis of innovation, industry contribution, integration with current product lines, migration capabilities, support provided and return on investment.

The Product of the Year Award category recognizes a new electronics product that stands out in the areas of design, innovation and usability and is successful in addressing a specific application. 


\begin{tabular}{|c|c|}
\hline $\begin{array}{l}\text { Frost \& Sullivan } \\
\text { Product Innovation } \\
\text { Award }\end{array}$ & $\begin{array}{l}\text { Every year, Frost \& Sullivan presents the Product Innovation Award to a } \\
\text { company that has demonstrated excellence in new products and } \\
\text { technologies within its industry. }\end{array}$ \\
\hline $\begin{array}{l}\text { Best of What's New } \\
\text { Awards }\end{array}$ & $\begin{array}{l}\text { Best of What's New Awards are presented } 100 \text { new products and } \\
\text { technologies in } 12 \text { categories: Auto Tech, Aviation \& Space, Cars, Computing, } \\
\text { Engineering, Gadgets, General Innovation, Home Entertainment, Home Tech, } \\
\text { Personal Health, Photography and Recreation. }\end{array}$ \\
\hline R\&D 100 Awards & $\begin{array}{l}\text { The prestigious R\&D } 100 \text { Awards have been helping firms provide the } \\
\text { important initial push a new product needs to compete successfully in the } \\
\text { marketplace. The winning of an R\&D } 100 \text { Award provides a mark of } \\
\text { excellence known to industry, government, and academia as proof that the } \\
\text { product is one of the most innovative ideas of the year. }\end{array}$ \\
\hline $\begin{array}{l}\text { Computing Awards } \\
\text { for Excellence }\end{array}$ & $\begin{array}{l}\text { Recognized as the 'benchmark for excellence' by the IT industry, the } \\
\text { Computing Awards for Excellence rewards high standards of achievement } \\
\text { and solutions that made a significant impact on business over the past year. } \\
\text { Evaluation criteria included functionality, performance, price, market } \\
\text { positioning, innovation, purpose and integration capabilities. }\end{array}$ \\
\hline
\end{tabular}

Notwithstanding these numerous NPIP schemes, to the best of our knowledge, there exist no significant and robust research to investigate into the impact of winning NPIP by the announcing firms on their stock prices. Therefore, the major objective of this study is to investigate empirically into the stock market reaction of the announcements of firms winning NPIP with particular focus on the CECI.

We agree with the study by [14] in which the authors believe that the CECI should not be mixed with other industries but should be analyzed separately when dealing with NPI. This is due to the fact that the CECI has much higher NPI rate than other industries. Hence, the focus of this research on the CECI. In the nutshell, this research aims to exploring the responsiveness of the stock market to NPIP awarded to new products as well as evaluate how some of the moderating factors influence the reaction of the stock market. The results of this paper could be a means of providing evidence of successful new products through efficient implementation of strategic decisions in areas of strategic and operations management as well as marketing. A positive stock market reaction to NPIP announcements would indicate that such an event disseminates valuable information to the market. This paper also highlights the significant roles the various NPIP schemes play in ensuring strict adherence to best management practices for firms which aims at winning such prizes. Additionally, these prize-giving institutions provide feedback mechanisms for the loosing firms with respect to the criteria they fell short for improvement purposes. The next section of this paper discusses the hypotheses. Chapter 3 captures the process of data collection and methodology used in this research. Chapter 4 covers the results of the study. The final chapter provides a conclusion of the research and recommends areas for future research.

\section{Stock Market Reaction to Winning NPIP}

\section{HYPOTHESES}

The magnitude of stock reaction to the announcements of firms winning NPIP is dependent on the level of expectations investors and other industry players place on the information contained in such announcements. In view of this, the fluctuations in stock prices is due to an investors' expectation of a company's present value and anticipating its future performance [26]. According to the efficient market theory, any new information is incorporated into the stock price as soon as it is publicized [27]. Investors are considered to be rational and purely interested in wealth-maximization in the form of abnormal returns after a critical risk/return trade-off evaluation [28]. [29] argue that the sign of the abnormal return is an indication of whether investors have sufficiently compensated for the risk based on the type of announcement as well as the nature of the information (good or bad) portrayed by the 
announcements. Announcements of firms being awarded NPIP is one of the events that has the tendency of triggering investors' expectation of abnormal returns. All the benefits associated with winning such a prize culminate into impacting on investors' expectation which triggers stock market reaction. This is evident in the conceptual model designed for this research as depicted in figure 2 which is briefly discussed as follows:

Free Publicity: Being awarded a prize can provide an advantage for the winning firm in augmenting its marketing strategies. The free advertisement received by the winning firm can create new connections and more business opportunities. This helps to confirm what the firm is into and also increase its presence in the market. The free publicity will increase existing customers' loyalty and attract new customers. This can result in enhancing the firm's topline and bottom-line financial performance.

Boost Morale: The workers of the prize-winning company will be proud to be part of the winning team as their firm has been recognized by an external entity. Such an external recognition will serve as an extra motivation for them to continue work diligently to win more laurels in future.

Builds Credibility: Such a recognition will demystify certain doubts lingering in the minds of prospective and disgruntled clients. Moreover, it will serve as an encouragement for the prospective customers to take the firm seriously even before conducting some background enquiries about the firm.

Attracts Talents: A firm achieving such feat is a means of boosting employee retention rate of the firm whiles serving as an attractive destination for topnotch job seekers.

Get an Edge Up: Being recognized at the top level by a distinguished prize-giving entity will help the firm to establish market leadership over its peers and competitors. It's a means of acquiring and maintaining competitive advantage in the marketplace.

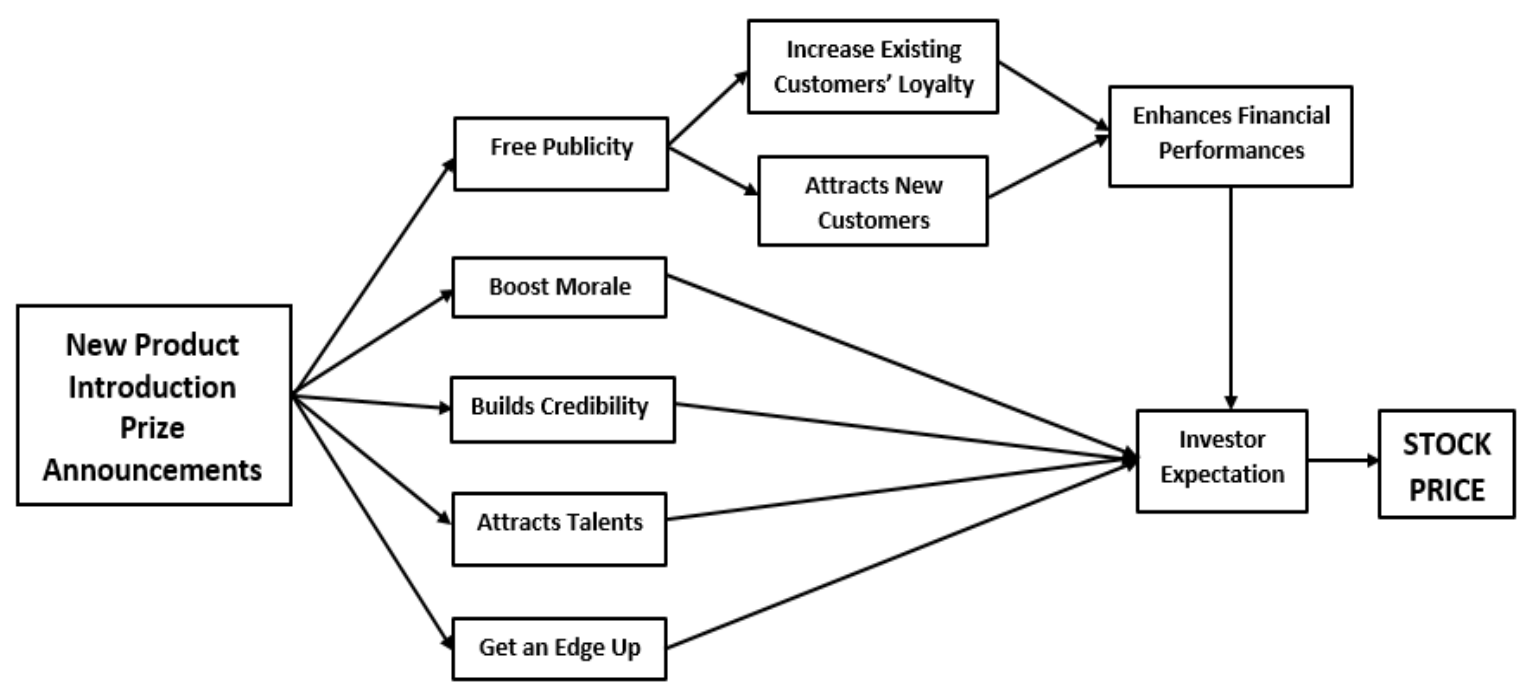

Figure 2: Conceptual model for linkage between NPIP announcements and the market value of a firm

Source: Authors' construct

The aforementioned benefits from winning NPIP can be a mechanism of portraying information about the company's new product development capabilities. Positive expectations are therefore arisen about the company's existing and future goods and services. The stock 
market reflects the positive expectations from investors and other stakeholders. The expectations of the company's future prospects in terms of the level of its profitability are updated subsequently. The positive expectation of investors as a result of NPIP announcements means that they expect to earn favorable abnormal returns. Thus, investors, shareholders and other industry players expect positive stock market reaction to this event. Accordingly, the first hypothesis is formulated as:

$\mathrm{H}_{1}$ : The stock market will react to NPIP announcements positively.

\section{The Reaction of the Stock Market to the Impact of Firm Characteristics}

The magnitude of reaction of the stock market is influenced by a number of factors which are worth considering in studies of this nature. This will provide comprehensive understanding of how the stock market reacts differently to conditions surrounding an event. Therefore, apart from the general stock market reaction to NPIP announcements as exhibited in hypothesis 1, we evaluate how the reaction of the market is influenced by some moderators in the form of firm characteristics such as firm size and source of prize.

\section{Firm Size}

Firm size is perhaps considered as one of the important moderating variables influencing the reaction of the market in operations researches. Therefore, this study investigates how the size of the winning firm will affect the magnitude of the stock market reaction by way of the average abnormal return estimated. It has been postulated that large-sized firms experience lower abnormal returns as a result of new product launches or being awarded a prize [30], [31]. [32] explain that the anticipation of information about large-sized firms is often higher than small-sized firms. As such, the media, financial experts and other industry players provide more attention to large-sized firms. Hence events and information emanating from larger firms are not surprising to the stock market in comparison with smaller firms. This discussion informs the formulation of the second hypothesis as:

$\mathrm{H}_{2}$ : The reaction of the stock market to winning NPIP will be more positive for small-sized firms than large-sized firms.

\section{Source of Prize}

The source of a prize given to a firm or an organization can also have an impact on the average abnormal mean calculated. There are many prize-giving institutions with different criteria for awarding the prizes to deserving firms. Some of the prizes are given by institutions along the firms' supply chain namely downstream and upstream players. Other prizes are awarded by third party organizations outside the firms' supply chain. The level of impact these two categories of prize-giving schemes have on the abnormal returns varies. Different prize-giving entities use different criteria for assessing the new product development capabilities of firms. Most prize-giving institutions along the supply chain require firms to participate in the prizegiving competition periodically. On the contrary, participation in third-party prize schemes is not mandatory. Moreover, the assessment criteria are more stringent for accepting entries in the third-party prize competitions than those set by prize-giving organizations within the firms' supply chain. As such third-party prize schemes are considered as having higher repute and prestige than prize-giving schemes within the firms' supply chain. This means that there is high probability for companies that possess higher levels of new product development capabilities to participate in the third-party prize competitions. Therefore, winning NPIP from third-party prize schemes may send a stronger signal to investors which may trigger more favorable market reaction. Hence, the third hypothesis is set as:

$\boldsymbol{H}_{3}:$ The market reaction to winning NPIP from third-party prize scheme will be more positive than winning from prize schemes within the firms' supply chain. 


\section{Data Collection}

\section{DATA AND METHODOLOGY}

Keyword searches were conducted using the Dow Jones Factiva database to identify NPIP winners for a period of 15 years (2001-2015). New product, prize, best, introduction, award, and recognition are some of the key words used in the searches. The searches were limited to three authoritative media outlets namely Business Wire, PR Newswire and Dow Jones Newswire. During the process of data collection, only firms with announcements about prizes given to new products introduced in a specific year within the study period were considered and included in the sample. However, we eliminated announcements of NPIP winners that will appear in non-daily publications when there is a problem in determining the exact date when information about the prize winner was first publicly available. For duplicate announcements, those with the earliest publication dates were maintained. Our initial sample consists of 536 announcements of listed companies on New York Stock Exchange (NYSE), American Stock Exchange (AMEX) and National Association of Securities Dealers Automated Quotations (NASDAQ) Exchange. Companies that have no sufficient stock price obtained from the Center for Research in Security Prices (CRSP) were also excluded from the sample. Therefore, the final sample used for this study is made up of 509 NPIP announcements for 221 distinct companies. Three examples of the announcements are listed as follows:

- SANTA CLARA, Calif., Oct. 23, 2001 (PRNewswire) - Continuing the networking industry's longest winning streak, Extreme Networks, Inc. (Nasdaq: EXTR) has again received the highest recognition for its Ethernet switch technology from Network+Interop. Extreme Networks was presented with the prestigious Network+Interop 2001 Best of Show Award for its SummitPx Application Switch, named the best new product in the performance enhancement category.

- NEW YORK, April 6, 2011 (PRNewswire) - Lockheed Martin (NYSE: LMT) MONAX 3G wireless communications system has been honored with a 2011 Edison Best New Product Award.

- HHUNTSVILLE, Ala. - (Business wire) - September 24, 2013 - ADTRAN Inc., (NASDAQ: ADTN), a leading provider of next-generation networking solutions, has been named the Gold Stevie Award winner at the 2013 Internal Business Awards within the categorizing "Best New Product or Service of the Year - Telecommunications Hardware" for its NetVanta and Total Access solutions with eSBC functionality.

Panels A and B of Table 2 present the yearly distribution of the sample announcements and their statistics using the nearest fiscal year completed before or after winning their first NPIP respectively. It can be observed from Table 1 that greater part of the announcements (368 representing $72.30 \%$ ) included in our sample were made between 2007-2015. The remaining (141 announcements representing 27.7\%) were made between 2001-2006. The concentration of the announcements made between $2007-2015$ is probably attributable to the massive coverage by the media and databases in contemporary years. Most importantly, it attests to the fact that the CECI is characterized by rampant NPIs in recent years. 
Table 2. Yearly distribution and statistics of sample announcements

\begin{tabular}{|c|c|c|c|c|}
\hline Year & & \multicolumn{2}{|c|}{ Number } & $\begin{array}{l}\text { Percentage } \\
(\%)\end{array}$ \\
\hline \multicolumn{5}{|c|}{ Panel A: Yearly distribution of the 509 sample announcements of winning NPIP } \\
\hline \multicolumn{2}{|c|}{2001} & 19 & & 3.73 \\
\hline \multicolumn{2}{|l|}{2002} & 16 & & 3.14 \\
\hline \multicolumn{2}{|l|}{2003} & 21 & & 4.13 \\
\hline \multicolumn{2}{|l|}{2004} & 29 & & 5.70 \\
\hline \multicolumn{2}{|l|}{2005} & 27 & & 5.30 \\
\hline \multicolumn{2}{|l|}{2006} & 29 & & 5.70 \\
\hline \multicolumn{2}{|l|}{2007} & 33 & & 6.48 \\
\hline \multicolumn{2}{|l|}{2008} & 44 & & 8.64 \\
\hline \multicolumn{2}{|l|}{2009} & 39 & & 7.66 \\
\hline \multicolumn{2}{|l|}{2010} & 34 & & 6.68 \\
\hline \multicolumn{2}{|l|}{2011} & 46 & & 9.04 \\
\hline \multicolumn{2}{|l|}{2012} & 49 & & 9.63 \\
\hline \multicolumn{2}{|l|}{2013} & 37 & & 7.27 \\
\hline \multicolumn{2}{|l|}{2014} & 31 & & 6.09 \\
\hline \multicolumn{2}{|l|}{2015} & 55 & & 10.81 \\
\hline \multicolumn{2}{|c|}{ Total } & 509 & & 100 \\
\hline \multicolumn{5}{|c|}{ Panel B: Description Statistics for the 509 announcements of winning NPIP } \\
\hline & $\begin{array}{l}\text { Total Assets } \\
\text { (million } \$ \text { ) }\end{array}$ & $\begin{array}{l}\text { Sales } \\
\text { (million \$) }\end{array}$ & $\begin{array}{l}\text { Market Value } \\
\text { (million \$) }\end{array}$ & $\begin{array}{l}\text { R/D } \\
\text { (million \$) }\end{array}$ \\
\hline Mean & 36398.93 & 22823.83 & 22434.49 & 1695.77 \\
\hline Median & 5589.32 & 4857.09 & 2119.19 & 358.45 \\
\hline Std. Dev. & $92,947.62$ & 36936.49 & 53545.67 & 2404.14 \\
\hline Maximum & 664142.69 & 220725.83 & 345423.67 & 11688.68 \\
\hline Minimum & 8.65 & 0.80 & 11.95 & 0.00 \\
\hline
\end{tabular}

\section{Methodology}

The event study methodology is adopted for this study. It is used to measure the effect of NPIP announcements on the stock price of the prize-winning firm the impact of NPIP announcements on the stock price of the prize-winning companies and the entire stock market. According to [33], event study methodology is used to estimate the effect of an event on a specific dependent variable (stock price). According to [30], the primary idea is to test the statistical significance of the mean abnormal returns on an event date for a sample of companies experiencing the same type of company-specific event. An important assumption underlying this methodology is that there must be efficiency in the market. The efficient market hypothesis postulates that any change in the stock price caused by an event or the release of new information will happen immediately which will enable investors and the general public to observe the economic effect in a relatively short period of time [33]. This is an extensively used methodology in fields like strategic management, finance and operation management. [15], [34]-[37]. In line with other studies we estimate the abnormal returns over two-day event window [38]. The trading day's activities on the stock exchanges considered for this research ends on 4:00 PM East Standard Time (EST). Day -1 and Day +1 are considered as the days after and before the day of the announcement respectively. The event days were derived from the calendar days as follows:

- For NPIP announcements made before 4:00 PM EST -

i. the calendar day of the announcement is Day 0 in event time,

ii. the next trading day is Day +1 ,

iii. the trading day preceding the announcement day is Day -1 , and so on. 
- For NPIP announcements made after 4:00 PM EST -

i. the announcement calendar day is Day -1 in event time,

ii. the next trading day is Day 0 ,

iii. the trading day preceding the announcement day is Day -2 , and so on.

The structure of the estimation period should be determined after defining the accurate event window. Thus, the estimation window is structured as follows:

- The estimation window is made up of 250 trading days, from Day $\mathrm{T}_{3}=-260$ to Day $\mathrm{T}_{2}=-$ 11. It is required for a company to have not less than 40 return observations during the estimation window of 250 trading days.

- Two weeks constituting ten trading days before the event date are not included in the estimation period in order to mitigate against any potential anticipation effects. According to [39], anticipation effect is where the stock market is able to anticipate new information or event in days before the formal release of the information. Figure 3 illustrates the structure of both the estimation and the event periods for this study.

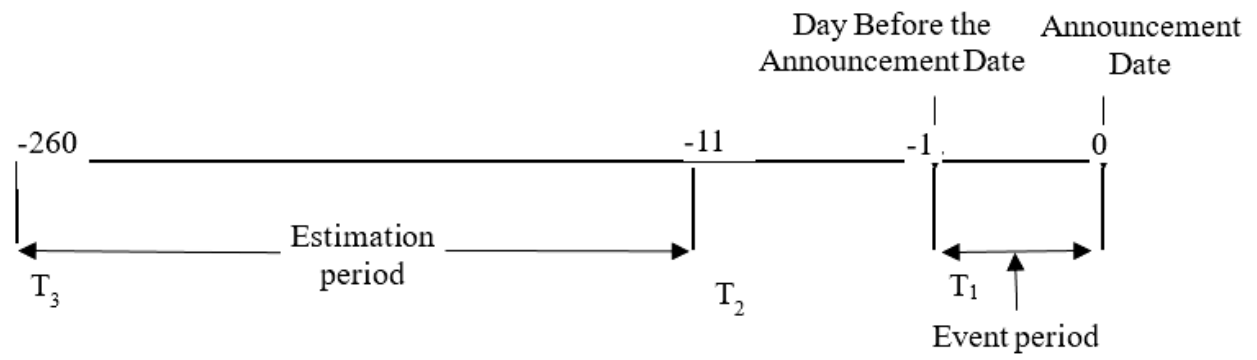

Figure 3: The structure of event period and estimated period of short-term Source: Authors' Construct

The market model is used to estimate the abnormal returns which is consistent with recent studies [39], [40]. The market model posits a linear relationship between the return on a stock and the market return over a given period of time and expressed as:

$$
\begin{aligned}
& \mathrm{R}_{\mathrm{it}}=\alpha_{\mathrm{i}}+\beta_{\mathrm{i}} \mathrm{R}_{\mathrm{mt}}+\varepsilon_{\mathrm{it}} \\
& \mathrm{E}\left[\varepsilon_{\mathrm{it}}\right]=0 ; \operatorname{Var}\left[\varepsilon_{\mathrm{it}}\right]=\sigma_{\varepsilon}^{2}
\end{aligned}
$$

where $\mathrm{R}_{\mathrm{it}}$ and $\mathrm{R}_{\mathrm{mt}}$ are the period $t$ returns on stock $i$ and the market portfolio respectively and $\varepsilon_{\mathrm{it}}$ is the disturbance term; and $\alpha_{\mathrm{i}}, \beta_{\mathrm{i}}$, and $\sigma_{\varepsilon}^{2}$ are the parameters of the model to be estimated. In this research, the CRSP equally-weighted index is chosen as the proxy for stock $i^{\prime} \mathrm{s}$ corresponding market portfolio. The parameters of the model, $\alpha_{i}, \beta_{i}$, and $\sigma_{\varepsilon}^{2}$ are estimated by using ordinary least squares regression (OLS) on data from the estimation period (i.e. from Day $\mathrm{T}_{3}$ to Day $\mathrm{T}_{2}$ ). Then, the abnormal return of stock $i$ on trading day $t$ in the event window is calculated as:

$$
A R_{i t}=R_{i t}-\widehat{\alpha}_{i}-\widehat{\beta}_{i} R_{m t}
$$

for $t \in\left\{\mathrm{T}_{1}\right.$, Day 0$\}$, where $\mathrm{AR}_{\mathrm{it}}$ is the abnormal return of stock $i$ at day $t$. Abnormal returns generated from an event is defined as the difference between the normal returns which would have occurred on that day given no event and the actual returns that did occur because of the event [41]. Then the average abnormal returns (AAR) over each day in the event period is calculated as: 


$$
\overline{\mathrm{AR}}_{\mathrm{it}}=\frac{\mathrm{AR}_{\mathrm{it}}}{\mathrm{N}}
$$

where $\mathrm{N}$ is the observations in the sample.

The cumulative average abnormal returns (CAR) in the event period is finally calculated as:

$$
\operatorname{AR}\left(\mathrm{t}_{1}, \mathrm{t}_{2}\right)=\sum_{\mathrm{t}=\mathrm{t}_{1}}^{\mathrm{t}=\mathrm{t}_{2}} \overline{\mathrm{AR}}_{\mathrm{it}}
$$

where $t_{1}$ and $t_{2}$ represent the beginning and the end of the event window.

\section{Significant Test of Abnormal Returns}

The test statistic, $\mathrm{TS}_{\mathrm{t}}$, for any Day $t$ is estimated as:

$$
\mathrm{TS}_{\mathrm{t}}=\frac{1}{\sqrt{\mathrm{N}}} \sum_{\mathrm{i}=1}^{\mathrm{N}} \frac{\mathrm{AR}_{\mathrm{it}}}{\widehat{\mathrm{S}}_{\overline{\varepsilon i}_{\mathrm{i}}}}
$$

The multiple day test statistics, $\mathrm{TS}_{\mathrm{c}}$, is estimated as:

$$
\mathrm{TS}_{\mathrm{c}}=\frac{1}{\sqrt{\mathrm{N}}} \sum_{\mathrm{i}=1}^{\mathrm{N}} \frac{\sum_{\mathrm{t}=\mathrm{t}_{1}}^{\mathrm{t}_{2}} \mathrm{AR} \mathrm{R}_{\mathrm{it}}}{\sqrt{\sum_{\mathrm{t}=\mathrm{t}_{1}}^{\mathrm{t}_{2}} \widehat{S}_{\mathrm{ii}}}}
$$

Equation (5) is the test statistic formula for equation (3) in order to determine the statistical significance of the average abnormal return. A standardized abnormal mean is estimated by dividing each abnormal return $\mathrm{AR}_{\mathrm{it}}$ by its estimated standard deviation $\widehat{\mathrm{S}}_{\varepsilon \mathrm{i}}$. The cumulative average abnormal returns (CAR) is tested for its statistical significance by the formula presented in Equation (6). There is underlying assumption that abnormal returns across events are not dependent. As such, the sum of the $\mathrm{N}$ standardized abnormal returns is approximately normal with mean 0 and variance $\mathrm{N}$. The central limit theorem forms the basis for this assertion.

Other two non-parametric tests were conducted to provide supplementary analysis to the ttests. This supplementary analysis is a mechanism for checking the influence of outliers. Wilcoxon signed-rank test is used to test the statistical significance of the median abnormal return whiles the binomial sign test is used to determine whether the percentage positive of the abnormal returns is significantly more than $50 \%$. All reported p-values are one-tailed because it is hypothesized that announcements of NPIP can only have a positive stock market reaction.

\section{Event Study Results}

\section{RESULTS}

Table 3 presents the results of the event study using the market model. The mean abnormal return for Day -1 is significant at $5 \%$ level while that of Day 0 is positive and significant at $1 \%$. The mean abnormal return is $0.21 \%$ for Day -1 and $0.46 \%$ for Day 0 . Moreover, the median abnormal returns for Days -1 and 0 are positive $(0.19 \%$ and $0.24 \%$ respectively) and significant at $5 \%$ and $1 \%$ levels respectively. The percentage of positive abnormal returns for Day -1 (10\% significant level) and Day 0 (5\% significant level) are $54.73 \%$ and $58.56 \%$ respectively, significantly higher than $50 \%$ based on the binomial sign test. This implies that the results generated by this study are not impacted by outliers. With regard to the two-day event period (Days -1 and 0 ), the mean abnormal returns (0.67\%) (1\% significant level) and median abnormal returns $(0.29 \%)$ (1\% significant level) are both positive. Furthermore, the two-day event window (Days -1 and 0 ) produced percentage of positive abnormal returns of $59.02 \%$ at $1 \%$ significant level by applying the binomial sign test. The percentage of abnormal 
returns for the two-day event window (Days -1 and 0 ) is significantly more than 50\%. This signifies that outliers have no impact on the results of this study. The results of the market model indicate that NPIP announcements yields positive stock market reaction.

Apart from the two-day event period, we also extended the analysis and examined market reaction over trading days: Day 1 and Day 2 after the event date. The results show significant positive abnormal returns for Day 1 at 10\% level using the market model. This positive significant abnormal returns for Day 1 are confirmed by the sensitivity analysis using the market-adjusted model at 5\% level. Furthermore, Table 3 depicts positive coefficient of abnormal returns but insignificant on Day 2.

Table 3. Market Model Abnormal Returns for 509 NPIP announcements

\begin{tabular}{llllll}
\hline & Day -1 & Day 0 & $\begin{array}{l}\text { Days -1 and } \\
\text { 0 (CAR) }\end{array}$ & Day 1 & Day 2 \\
\hline Sample Size & 509 & 509 & 509 & 509 & 509 \\
Mean Abnormal Returns (\%) & 0.21 & 0.46 & 0.67 & 0.39 & 0.27 \\
Median Abnormal Returns (\%) & 0.19 & 0.24 & 0.29 & 0.22 & 0.18 \\
\% of Positive Abnormal Returns & 54.73 & 58.56 & 59.02 & 56.31 & 53.70 \\
t-statistic & $1.54^{* *}$ & $2.55^{* * *}$ & $3.14^{* * *}$ & $1.47^{*}$ & 1.21 \\
Wilcoxon Signed-rank Z-statistic & $1.61^{* *}$ & $2.52^{* * *}$ & $2.78^{* * *}$ & 1.23 & 1.34 \\
Binomial Sign test Z-statistic & $1.29^{*}$ & $2.44^{* *}$ & $1.88^{* *}$ & 1.04 & 0.97 \\
\hline
\end{tabular}

$*, * *$, and ${ }^{* * *}$ denote statistically significant at 10\%,5\% and 1\% levels respectively for mean abnormal return (t-statistics) and median abnormal returns (Wilcoxon sign-ranked test) respectively. ${ }^{*}, * *$ and ${ }^{* * *}$ represent $10 \%, 5 \%$ and $1 \%$ significantly higher than $50 \%$ as in the case of Binomial sign test for the \% positive abnormal returns. All tests are one-tailed.

A number of additional tests using the market model have been performed to ensure the robustness of our results. Table 4 illustrates four further robustness tests for the CAR which covers the event window, Days -1 and 0 . The market model are used to execute all the robustness tests. The market model estimation period is changed to 200 days, 150 days, 100 days and 50 days as presented in Table 4 under rows (i), (ii), (iii) and (iv) respectively. It has been discovered that the significance levels and magnitude of the CARs for the two-day event window (Days -1 and 0 ) are similar to results attained with the baseline settings in Table 3. 
Table 4. Further robustness tests of Days -1 and 0 (CAR)

\begin{tabular}{|c|c|c|c|c|c|c|c|}
\hline & $\mathrm{N}$ & $\begin{array}{l}\text { Mean } \\
\text { abnormal } \\
\text { returns } \\
(\%)\end{array}$ & $\begin{array}{l}\text { Median } \\
\text { abnormal } \\
\text { returns (\%) }\end{array}$ & $\begin{array}{l}\% \text { of positive } \\
\text { abnormal } \\
\text { returns }\end{array}$ & $\begin{array}{l}\mathrm{t}- \\
\text { statistic }\end{array}$ & $\begin{array}{l}\text { Wilcoxon } \\
\text { signed- } \\
\text { rank Z- } \\
\text { statistic } \\
\end{array}$ & $\begin{array}{l}\text { Binomial sign } \\
\text { test Z- } \\
\text { statistic }\end{array}$ \\
\hline $\begin{array}{l}\text { (i) Estimation } \\
\text { period }(-210,-11)\end{array}$ & 509 & 0.61 & 0.24 & $58.46 \%$ & $2.59 * * *$ & $1.83^{* *}$ & $2.21^{* *}$ \\
\hline $\begin{array}{l}\text { (ii) Estimation } \\
\text { period }(-160,-11)\end{array}$ & 509 & 0.54 & 0.15 & $54.71 \%$ & $1.48^{*}$ & $2.31^{* *}$ & $1.59 * *$ \\
\hline $\begin{array}{l}\text { (iii)Estimation } \\
\text { period }(-110,-11)\end{array}$ & 509 & 0.69 & 0.47 & $62.37 \%$ & $4.31^{* * *}$ & $3.09 * * *$ & $1.44^{*}$ \\
\hline $\begin{array}{l}\text { (iv)Estimation } \\
\text { period }(-60,-11)\end{array}$ & 509 & 0.58 & 0.21 & $56.06 \%$ & $1.86^{* *}$ & $1.79^{* *}$ & $2.38^{* * *}$ \\
\hline
\end{tabular}

$*, * *$, and ${ }^{* * *}$ denote statistically significant at $10 \%, 5 \%$ and $1 \%$ levels respectively for mean abnormal return (t-statistics) and median abnormal returns (Wilcoxon sign-ranked test) respectively. ${ }^{*}, * *$ and ${ }^{* * *}$ represent $10 \%, 5 \%$ and $1 \%$ significantly higher than $50 \%$ as in the case of Binomial sign test for the $\%$ of positive abnormal returns. All tests are one-tailed.

To avoid the results being influenced by the choice of the market model, sensitivity analysis was conducted using other two models: the market adjusted model and the mean adjusted model. The abnormal return, $\mathrm{AR}_{\mathrm{it}}$, under market adjusted model is calculated as:

$$
\mathrm{AR}_{\mathrm{it}}=\mathrm{R}_{\mathrm{it}}-\mathrm{R}_{\mathrm{mt}}
$$

In comparison with the market model illustrated in Equation (2), the market adjusted model postulates that every company has characteristics to the entire market $\left(\widehat{\alpha}_{i}=0\right.$ and $\left.\widehat{\beta}_{i}=1\right)$. The mean abnormal return, $\overline{\mathrm{AR}}_{\mathrm{it}}$, on day $\mathrm{t}$ is then estimated using:

$$
\overline{\mathrm{AR}}_{\mathrm{it}}=\frac{1}{\mathrm{~N}_{\mathrm{t}}} \sum_{\mathrm{t}=1}^{\mathrm{N}_{\mathrm{t}}} \mathrm{A}_{\mathrm{it}}
$$

where $\mathrm{N}_{\mathrm{t}}$ is the number of stocks with return information on day $t$.

Under the mean adjusted model, it uses as benchmark the stock's daily return over the estimation window. The abnormal return, $\mathrm{AR}_{\mathrm{it}}$, is calculated by applying:

$$
\begin{aligned}
& \mathrm{AR}_{\mathrm{it}}=\mathrm{R}_{\mathrm{it}}-\overline{\mathrm{R}}_{\mathrm{t}} \\
& \overline{\mathrm{R}}_{\mathrm{t}}=\frac{1}{\text { Dest }} \sum_{\mathrm{t} \in \mathrm{EstP}} \mathrm{R}_{\mathrm{it}}
\end{aligned}
$$

where $\overline{\mathrm{R}}_{\mathrm{t}}$ is the simple average of stock $i$ 's daily over EstP, the estimation period $(-260 \leq$ Days $\leq$ -11) and Dest, the number of trading days in the estimation window (250 days).

Table 5 presents the results of the sensitivity analysis. Generally, the results obtained by way of the sensitivity analysis are similar with the results of the market model (Ref. Table 3). From Table 5, the two-day event period (Days -1 and 0 ) generated positive mean abnormal return of $0.61 \%$ (significant at $1 \%$ ) and positive median abnormal return $0.32 \%$ (significant at $1 \%$ ) using the market adjusted model. Under the mean adjusted model, the results churned out were positive mean abnormal returns of $0.58 \%$ (significant at $10 \%$ ) and positive median abnormal return of $0.28 \%$ (significant at 10\%). Additionally, percentage of positive abnormal returns are 57.39\% (market adjusted) and 51.87\% (mean adjusted) which are greater than 50\% (significant at 10\%) for both models. 
Table 5. Sensitivity Analysis for 509 NPIP announcements

\begin{tabular}{llllll}
\hline & Day -1 & Day 0 & $\begin{array}{l}\text { Days -1 and } \\
\text { 0 (CAR) }\end{array}$ & Day 1 & Day 2 \\
\hline Panel A - Market Adjusted & & & & & \\
Sample Size & 509 & 509 & 509 & 509 & 509 \\
Mean Abnormal Returns (\%) & 0.21 & 0.40 & 0.61 & 0.33 & 0.15 \\
Median Abnormal Returns (\%) & 0.22 & 0.26 & 0.32 & 0.19 & 0.21 \\
\% of Positive Abnormal Returns & 52.45 & 55.10 & 57.39 & 54.46 & 51.89 \\
t-statistic & $1.61^{* *}$ & $2.37^{* * *}$ & $3.05^{* * *}$ & $1.51^{* *}$ & 1.14 \\
Wilcoxon Signed-rank Z-statistic & $1.40^{*}$ & $1.69^{* *}$ & $2.64^{* * *}$ & 0.83 & 1.01 \\
Binomial Sign test Z-statistic & $1.43^{*}$ & $1.48^{*}$ & $1.45^{*}$ & 1.24 & 0.85 \\
& & & & & \\
Panel B - Mean Adjusted & & & & & \\
Sample Size & 509 & 509 & 509 & 509 & 509 \\
Mean Abnormal Returns (\%) & 0.19 & 0.39 & 0.58 & 0.26 & 0.15 \\
Median Abnormal Returns (\%) & 0.07 & 0.18 & 0.28 & -0.17 & -0.13 \\
\% of Positive Abnormal Returns & 50.50 & 53.33 & 51.87 & 46.33 & 48.50 \\
t-statistic & 1.39 & $1.42^{*}$ & $1.47^{*}$ & 0.32 & 0.29 \\
Wilcoxon Signed-rank Z-statistic & $1.41^{*}$ & $1.47^{*}$ & $1.90^{*}$ & -0.27 & -0.21 \\
Binomial Sign test Z-statistic & 0.08 & 1.29 & $1.41^{*}$ & -0.41 & -0.33 \\
\hline
\end{tabular}

$*, * *$, and ${ }^{* * *}$ denote statistically significant at the $10 \%, 5 \%$ and $1 \%$ levels respectively for mean abnormal return (t-statistics) and median abnormal returns (Wilcoxon sign-ranked test) respectively. ${ }^{*}, * *$ and ${ }^{* * *}$ represent $10 \%, 5 \%$ and $1 \%$ significantly higher than $50 \%$ as in the case of Binomial sign test for the \% positive abnormal returns. All tests are one-tailed.

Based on the analyses, the overall test results of the mean abnormal returns, median abnormal returns and percentage of positive abnormal returns in relation to all the three models during the period under study is an indication that the stock market's responsiveness to NPIP announcements within the CECI is positive. This result supports Hypothesis 1 . The magnitude of positive stock market reaction portrayed by this research is consistent with the mean CAR obtained by other studies which investigated into stock market reaction to new events or information: $0.75 \%$ [15], 0.96\% [42], 0.63\% [43], 0.39\% [44], 2.72\% [45] and $1.21 \%$ [32].

\section{Cross-Sectional Analysis Results}

It has been espoused that the magnitude of stock market reaction to new event or information is influenced by other moderating factors. Two of such moderating factors have been considered for this research of which hypotheses 2 and 3 were formulated accordingly. Therefore, a cross-sectional ordinary least square (OLS) regression model was developed to test hypotheses 2 and 3 . The hypotheses were tested using these various variables to represent them.

FirmSize: This variable is estimated by taking the natural logarithm of sales generated by the winning company in the year ending before the NPIP announcement date. The coefficient of this variable is expected to be negative.

ThirdpartyPrize: The value of 1 is assigned to this indicator variable if a company wins NPIP from third-party prize scheme but assumes 0 otherwise. This variable is expected to have a positive coefficient.

Apart from the moderating factors of firm characteristics, reputation and R\&D intensity have been chosen as control variables in the analysis.

Reputation: This depicts the reputation of a firm. Reputation is identified as an intangible asset, important in sustaining competitive advantages and therefore leading to greater returns 
[46]-[48]. Media coverage and market awareness for firms of high reputation winning a NPIP may be higher than firms of low reputation. As such, we control for reputation in order to mitigate any potential bias against firms with lesser reputation. The ranking in the Fortune World's Most Admired Companies list is considered an acceptable proxy for reputation with comparable data over an extended period of time, large number of respondents, and respondents that rate only companies in an industry with which they are familiar [49]. Hence, this study adopts the Fortune World's Most Admired Companies rankings as the measure of reputation. Consistent with other studies [32], [50], missing values were replaced with the industry average reputation sore.

$\boldsymbol{R} \& D I n t e n s i t y:$ This represents the research and development (R\&D) prowess of a company. It is regarded as a proxy for a company's new product development capabilities and likely to be responsible for its success economically [39]. R\&DIntensity is calculated by expressing company's R\&D expenditure divided by its sales generated during the fiscal year ending before the NPIP announcement date [51]. R\&DIntensity controls the impact of a company's new product development capabilities on the responsiveness of the market as a result of NPIP announcements.

The regression model used to test hypotheses 2 and 3 is expressed as:

CAR $_{i}=\beta_{0}+\beta_{1}$ FirmSize $_{i}+\beta_{2}$ ThirdpartyPrize $_{i}+\beta_{3}$ Reputation $_{i}+\beta_{4}$ R\&DIntensity $_{i}+\varepsilon_{i}$

where $\mathrm{CAR}_{\mathrm{i}}=$ cumulative abnormal return for firm $i$ covering the two-day event period $\varepsilon_{\mathrm{i}} \quad=$ disturbance term

Table 6 shows the Pearson correlation matrix between variables. The highest of the correlation coefficient (0.52) The correlation coefficient (highest being 0.52 ) and the collinearity statistics show no evidence of multicollinearity as all the variance inflation factor (VIF) is less than the ceiling (10.0) [52]. A two-stage analysis of regression results is presented in Table 7. The control variables are only included in the initial stage but stage two involves the inclusion of each variable. The initial stage resulted in an adjusted $R^{2}$ of 0.49 but increased to $0.52\left(\Delta \mathrm{R}^{2}=\right.$ 0.05 ) in stage two. This is indicating about $52 \%$ of the total variability in the CARs is explained by tested variables. The adjusted $\mathrm{R}^{2}$ of 0.52 is reasonably good and comparable to other studies investigating into stock market reaction to new events or information such as 0.57 reported by [53].

Table 7 shows that firm size has a negative coefficient at 1\% level of significance, indicating that the responsiveness of the stock market is more positive for NPIP announcements for small-sized firms than large-sized firms. Hence, the result supports hypothesis 2 which states that the reaction of the stock market to winning NPIP will be more positive for small-sized firms than large-size firm.

As hypothesized, the reaction of the market to firms winning NPIP from third-party prize scheme is more positive than from prize schemes within the firm's supply chain. This is evidenced in Table 7 which depicts a positive coefficient and significant at $10 \%$. The results could be attributable to the higher level of competition, greater prestige and the stringency in evaluating new product development capabilities of the participating firms by the third-party prize schemes. Thus, the result supports hypothesis 3.

Table 7 also portrays that all the control variables have positive coefficient, however none of them are statistically significant. Thus, this study suggests that research \& development and 
reputation of a firm are insignificant factors that impact on the market reaction as a result of announcements of firms winning NPIP under CECI.

Table 6. Sensitivity Analysis for 509 NPIP announcements

\begin{tabular}{lllllll}
\hline & Variable & 1 & 2 & 3 & 4 & 5 \\
\hline 1. & CAR & 1 & & & & \\
2. & FirmSize & $0.62^{* *}$ & 1 & & & \\
3. & ThirdpartyPrize & $0.50^{* *}$ & 0.18 & 1 & & \\
4. & Reputation & 0.06 & $0.45^{* *}$ & 0.09 & 1 & \\
5. & R\&DIntensity & 0.11 & $0.71^{*}$ & 0.16 & $0.39^{*}$ & 1 \\
\hline
\end{tabular}

* and ${ }^{* *}$ denote 0.05 and 0.01 significant levels respectively.

Table 7. Results of Regression Model

\begin{tabular}{|c|c|c|c|c|c|c|c|}
\hline Variables & Stage 1 & & & Stage 2 & & & \\
\hline & Coefficient & $t$-value & $\begin{array}{l}\text { Significant } \\
\text { level }\end{array}$ & Coefficient & $t$-value & $\begin{array}{l}\text { Significant } \\
\text { level }\end{array}$ & VIF \\
\hline F value & 10.68 & & $* * *$ & 6.02 & & $* * *$ & \\
\hline $\mathrm{N}$ & 509 & & & 509 & & & \\
\hline $\mathrm{R}^{2}$ (adjusted) & 0.49 & & & 0.52 & & & \\
\hline R\&DIntensity & 0.02 & 0.32 & & 0.02 & 0.87 & & 1.42 \\
\hline Reputation & 0.06 & 1.29 & & 0.07 & 1.32 & & 1.65 \\
\hline ThirdpartyPrize & & & & 0.02 & 1.47 & * & 1.18 \\
\hline FirmSize & & & & -0.05 & -2.63 & *** & 1.30 \\
\hline Constant & 0.22 & 2.34 & ** & 0.39 & 3.83 & $* * *$ & \\
\hline
\end{tabular}

$*, * *$ and ${ }^{* * *}$ denote $10 \%, 5 \%$ and $1 \%$ significant levels respectively.

\section{CONCLUSION}

The CECI in recent years has experienced incessant NPIs by the firms in their quest to achieve and sustain competitive advantage over their rivals. Successful NPIs are manifestation of the high levels of the firms' new product development capabilities. Following such successful NPIs, the new products could be awarded NPIP after meeting the criteria or requirements set by the prize-giving institutions. Being awarded such a prize after being subjected to an independent evaluation and assessment processes, provides investors, shareholders as well as the general public with credible and validated evidence of the effectiveness of the new product development systems implemented. Information from such recognition from the various prize schemes has the tendency of triggering market reaction. Therefore, this study has empirically investigated the effect of winning NPIP on a company's stock price by calculating the mean abnormal returns that accrues to a sample of winning companies of NPIP on the date when the announcement was publicized. Generally, the results indicate that the responsiveness of the stock market to NPIP announcements for firms in the CECI is positive. This study contributes significantly to the sparse literature that exist about the responsiveness of the market to announcements in CECI, but complements the extant literature about the reaction of the stock market to new events or information in general. The evidence exhibited in our research is consistent with other theoretical and empirical studies that have established positive stock market reaction to new events or information [49], [54], [55]. On the contrary, studies such as [56], [57] established that the market responds negatively to the respective events empirically investigated into. To the best of the authors' knowledge, this study is the first to empirically establish positive financial effect on the announcements of firms winning NPIP in CECI.

As our study has provided irrefutable scientific demonstration on the effect of winning NPIP on the value of the firm, managers of firms should set a prize-winning objective encapsulated into the overall organizational objective; wherefore taking strategic and operational decisions which will enhance their new product development capabilities in order to accomplish such an objective. Moreover, winning a NPIP can be regarded as reliable and inexpensive means of 
signaling to customers, investors and the general public that the company has adopted and successfully executed an effective new product development system. Furthermore, boosting of employee's morale, building of credibility, attracting talents and getting an edge up over rivals are some of the benefits that the prize-winning firm will enjoy from being awarded NPIP.

Researchers, investors, managers and the general public should exercise caution to generalize our results beyond the time period (2001-2015), event window ( 2 days [Days -1 and 0]), estimation window (250 trading days), specific event (NPIP announcements), data sample (509) and specific industry (CECI) chosen for this research. However, these limitations provide several avenues for future research. Firstly, this research has been conducted to establish a short-term effect on firm value on firm value due to NPIP announcements about firms within CECI within two-day event period (Days -1 and 0). This research recommends that further investigation should be conducted to estimate the long-term impact of the reaction of the stock market to announcements of firms winning NPIP in the CECI. Secondly, the sample used in this study constitute only firms in the CECI which won NPIPs. Thus, it would be intriguing to research into responsiveness of the market to the announcements of firms that were subjected to the evaluation and assessment process but did not win the prize. Thirdly, the CECI has been focus of this research. As such, it would be very informative for future research to be conducted for firms in other industries to establish the magnitude of reaction of the stock market to their NPIP announcements. Lastly, surveys or case studies could be conducted to reveal how the benefits (free publicity, boost morale, build credibility, attracts talents and get an edge up) of winning NPIP influence firm performance.

\section{References}

[1]. Business.com, “Do Awards Really Do Anything for Your Company?" 2017. [Online]. Available: https://www.business.com/articles/do-awards-really-do-anything-for-your-company/. [Accessed: 26Jul-2018].

[2]. W. M. Cohen and D. A. Levinthal, "Absorptive capacity: A new perspective on learning and innovation," Adm. Sci. Q. 35, vol. 35, pp. 128-152, 1990.

[3]. P. Gerosky, S. Machin, and C. Walters, "Corporate growth and profitability," J. Ind. Econ., vol. XLV, pp. 171$189,1997$.

[4]. P. A. Geroski and M. Mazzucato, "Learning and the sources of corporate growth, Industrial and Corporate Change," Oxford Univ. Press, vol. 11, no. 4, pp. 623-644, 2002.

[5]. C. C. Alberto, "Firm age and the probability of product innovation. Do CEO tenure and product tenure matter?," in The Governance of a Complex World, 2014.

[6]. S. Chen, K. W. Ho, and K. H. Ik, "The Wealth Effect of New Product Introductions on Industry Rivals," J. Bus., vol. 78, no. 3, pp. 969-996, 2005.

[7]. B. L. Bayus, G. Erickson, and R. Jacobson, "The Financial Rewards of New Product Introductions in the Personal Computer Industry," Manage. Sci., vol. 49, no. 2, pp. 197-210, 2003.

[8]. Y. Lin, S. Ma, and L. Zhou, "Manufacturing strategies for time based competitive advantages," Ind. Manag. Data Syst., vol. 112, no. 5, pp. 729-747, 2012.

[9]. A. Sapkauskiene and S. Leitoniene, "The concept of time-based competition in the context of management theory," Eng. Econ., vol. 21, no. 2, pp. 205-213, 2010.

[10]. R. Rosas-Vega and R. J. Vokurka, "New product introduction delays in the computer industry.," Ind. Manag. Data Syst., vol. 100, no. 4, pp. 157-163, 2000.

[11]. J. Chen, R. R. Reilly, and G. S. Lynn, “New product development speed: Too much of a good thing?," J. Prod. Innov. Manag., vol. 29, no. 2, pp. 288-303, 2012.

[12]. S. Datar, J. C., S. Kekere, S. Rajiv, and K. Srinivasan, "Advantages of time-based new product development in a fast cycle industry,” J. Mark. Res., vol. 34, no. 1, pp. 36-49, 1997. 
[13]. E. Więcek-Janka, M. Papierz, M. Kornecka, and M. Nitka, "Apple products: A discussion of the product life cycle," in 4th International Conference on Management Science and Management Innovation, 2017, vol. 31, no. August, pp. 159-164.

[14]. S. Ganna, "The Impact of New Product Introduction on the Financial Performance in the Notebook Industry," Kyiv School of Economics, 2013.

[15]. P. K. Chaney, T. M. Devinney, and R. Winer, "The Impact of New Product Introductions on the Market Value of Firms," J. Bus., vol. 64, no. 4, pp. 573-610, 1991.

[16]. Z. Zantout and R. Chaganti, "New product introductions, shareholders' wealth and first-mover advantages," J. Financ. Strateg. Decis., vol. 9, pp. 49-61, 1996.

[17]. K. H. Pauwels, J. Silva-Risso, S. Srinivasan, and D. Hanssens, "The Long-Term Impact of New-Product Introductions and Promotions on Financial Performance and Firm Value," Soc. Sci. Res. Netw., 2003.

[18]. A. Sorescu, V. Shankar, and T. Kushwaha, "New Product Preannouncements Shareholder Value: Don't make Promises You Can't Keep," J. Mark. Res., vol. 44, no. 3, pp. 468-489, 2007.

[19]. R. P. Lee and Q. Chen, "The immediate impact of new product introductions on stock price: The role of firm resources and size," J. Prod. Innov. Manag., vol. 26, no. 1, pp. 97-107, 2009.

[20]. F. Hao, R. Dixon, and T. Wang, "Stock market reactions to new product announcements: the role of investor sentiment," Bus. Manag. Rev., vol. 8, no. 4, pp. 234-245, 2017.

[21]. F. Paul, "Do New Product Announcements Have an Impact on Stock Prices of Consumer Electronic Firms?," Lund University, 2015.

[22]. HME Business, "HME Business New Product Award," 2018. [Online]. Available: https://hmebusiness.com/pages/new-product-award.aspx. [Accessed: 06-Aug-2018].

[23]. R. Vetschera, "A multi-criteria agency model with incomplete preference information," Eur. J. Oper. Res., vol. 126, no. 1, pp. 152-165, 2000.

[24]. J. L. Nicolau and M. J. Santa-María, "Communicating excellence in innovation," Econ. Lett., vol. 118, no. 1, pp. 87-90, 2013.

[25]. M. N. Saunders, C. C. Seepersad, and K. Hölttä-Otto, "The Characteristics of Innovative, Mechanical Products," 2009, pp. 1-38.

[26]. P. L. Yadav, S. H. Han, and J. J. Rho, "Impact of Environmental Performance on Firm Value for Sustainable Investment: Evidence from Large US Firms," Bus. Strateg. Environ., vol. 25, no. 6, pp. 402-420, 2015.

[27]. C. O. Udoka and B. I. Ibor, "An Assessment of Theories Underlying the Operations of the Nigerian Stock Market," Int. J. Bus. Soc. Res., vol. 4, no. 7, pp. 77-86, 2014.

[28]. A. Jagongo and V. S. Mutswenje, "A Survey of the Factors Influencing Investment Decisions: The Case of Individual Investors at the NSE," Int. J. Humanit. Soc. Sci., vol. 4, no. 4, pp. 92-102, 2014.

[29]. J. M. Bacidore, J. A. Boquist, T. T. Milbourn, and A. V Thakor, "The Search for the Best Financial Performance Measure," Financ. Anal. J., vol. 53, no. 3, pp. 11-20, 1997.

[30]. B. K. Hendricks and R. V. Singhal, "Quality Awards and the Market Value of the Firm: AnEmpirical Investigation," Manage. Sci., vol. 42, no. 3, pp. 415-436, 1996.

[31]. E. Jones and J. Danbolt, "Empirical evidence on the determinants of the stock market reaction to product and market diversification announcements," Appl. Financ. Econ., vol. 15, no. 9, pp. 623-629, 2005.

[32]. Y. Xia, V. R. Singhal, and G. P. Zhang, "Product design awards and the market value of the firm," Prod. Oper. Manag., vol. 25, no. 6, pp. 1038-1055, 2016.

[33]. C. Liang, "The Impact of Merger and Acquisition Announcements on Firms' Stock Performance: Evidence from Hong Kong Stock Market," Saint Mary's University, 2013.

[34]. J. Agrawal and W. A. Kamakura, "The Economic Worth of Celebrity Endorsers: An Event Study Analysis," J. Mark., vol. 59, pp. 56-62, 1995.

[35]. C. J. Corbett, M. J. Montes-Sancho, and D. A. Kirsch, "The financial impact of ISO 9000 certification in the United States: An empirical analysis," Manage. Sci., vol. 51, no. 7, pp. 1046-1059, 2005.

[36]. P. Yuan, "The Impact of New Product Announcements on stock Prices: Case for the Technology sector in the USA," Saint Mary's University, 2012. 
[37]. D. Li and Y. Mu, "Sustainability awards and the market value of the firm: An empirical investigation," in 14th International Conference on Services Systems and Services Management, 2017, pp. 1-6.

[38]. S. J. Brown and J. B. Warner, “Using daily stock returns: The case of event studies,” J. financ. econ., vol. 14, no. 1, pp. 3-31, 1985.

[39]. S. Ba, L. L. Lisic, Q. Liu, and J. Stallaert, "Stock Market Reaction to Green Vehicle Innovation," Prod. Oper. Manag., vol. 22, no. 4, pp. 976-990, 2013.

[40]. W. Y. Wong and C. W. Hooy, "The impact of election on stock market returns of government-owned banks: The case of Indonesia, Malaysia and Thailand," Asian J. Bus. Account., vol. 9, no. 1, pp. 31-58, 2016.

[41]. J. Ma, J. a Pagán, and Y. Chu, “Abnormal Returns to Mergers and Acquisitions in Ten Asian Stock Markets,” Int. J. Bus., vol. 14, no. 3, pp. 235-250, 2009.

[42]. K. M. Kelm, V. K. Narayanan, and G. E. Pinches, "Shareholder value creation during R\&D innovation and commercialization stages,” Acad. Manag. J., vol. 38, no. 3, pp. 770-786, 1995.

[43]. R. D. Klassen and C. P. McLaughlin., "The impact of environmental management on firm performance," Manage. Sci., vol. 42, no. 8, pp. 1199-1214, 1996.

[44]. D. S. Docking and R. J. Dowen, “Market interpretation of ISO 9000 registration,” J. Financ. Res., vol. 22 , no. 2, pp. 147-160, 1999.

[45]. A. Wong, Y. K. Cheung, and T. Mun, "The Effects of Merger and Acquisition Announcements on the Security Prices of Bidding Firms and Target Firms in Asia," Int. J. Econ. Financ., vol. 1, no. 2, pp. 274-283, 2009.

[46]. M. E. Porter, Competitive Advantage: Creating and Sustaining Superior Performance. Free Press: New York., 1985.

[47]. G. H. Jones, H. Jones, and P. Little, "Reputation as reservoir: Buffering against loss in times of economic crisis,” Corp. Reput. Rev. 3, 21-29., vol. 3, pp. 21-29, 2000.

[48]. K. E. Schnietz and M. J. Epstein, "Exploring the Financial Value of a Reputation for Corporate Social Responsibility during a Crisis,” Corp. Reput. Rev., vol. 7, no. 4, pp. 327-345, 2005.

[49]. A. I. M. Berg-boersma, "Reputation and its effect on stock return during the 2008 Stock Market Crisis," Open University Netherlands, 2018.

[50]. Y. Chen, S. Ganesan, and Y. Liu, “Does a Firm's Product-Recall Strategy Affect Its Financial Value? An Examination of Strategic Alternatives During Product-Harm Crises,” J. Mark., vol. 73, pp. 214-226, 2009.

[51]. B. A. Badertscher, P. S. Hribar, and N. T. Jenkins, "Informed trading and the market reaction to accounting restatements," Account. Rev., vol. 86, no. 5, pp. 1519-1547, 2011.

[52]. P. Kennedy, Guide to Econometrics, 4th ed. The MIT Press, Cambridge, MA., 1998.

[53]. D. K. Ding and C. Charoenwong, "Stock market reaction when listed companies in Singapore appoint female directors,” Int. J. Manag., vol. 30, no. 1, p. 285-300., 2013.

[54]. J. Woolridge, "Competitive decline and corporate restructuring: Is a myopic stock market to blame?," J. Appl. Corp. Financ., vol. 1, no. 1, pp. 26-36, 1988.

[55]. F. Rossi and R. Cebula, "Stock Market Reactions to Announcements of Board of Director Appointments: Evidence from Italy," 58403, 2013.

[56]. W. N. Davidson and D. L. Worrell, "The Effect of Product Recall Announcements on Shareholder Wealth," Strateg. Manag. J., vol. 13, no. 6, pp. 467-473, 1992.

[57]. H. C. Anderson-Weir, "How Does the Stock Market React to Corporate Environmental News?," Undergrad. Econ. Rev., vol. 6, no. 1, pp. 1-31, 2010. 